\title{
有機電解合成のための機能性界面の構築
}

\author{
柏木良友
}

\section{Construction of Functional Electrode Interface for Electroorganic Synthesis}

\author{
Yoshitomo KASHIWAGI \\ School of Pharmaceutical Sciences, Ohu University, 31-1 Misumido, Tomita-machi, \\ Koriyama City, Fukushima 963-8611, Japan
}

(Received April 2, 2007)

\begin{abstract}
Thin poly (acrylic acid) (PAA)-coated graphite felt (GF) is a promising electrode material for preparative organic electrosynthesis, because the electrode is not only stable and durable but also can be modified with various mediators and enzymes in the PAA layer. The TEMPO-modified GF electrode for electrocatalytic oxidation of several types of organic compounds were successfully constructed. The modified electrode had many advantageous properties compared with direct electrosynthesis or mediatory reaction synthesis which is still common as an electrochemical system. The use of a chiral nitroxyl radical-modified GF electrode afforded enantioselective oxidation of racemic alcohols or amines (remaining optically pure alcohols or amines) and asymmetric lactonization of methyl-substituted diols. A preparative electrocatalytic radical cyclization of bromo alkyl cyclohexenones was successfully achieved on a nickel (II) tetraazamacrocyclic complex-modified GF electrode. The PAA-coated GF electrode modified with viologen and palladium metal microparticles is effective for the electrocatalytic hydrogenation of olefins. An electrode immobilizing all components of mediator, enzyme, and coenzyme for electroenzymatic reactions was also prepared, and several electroenzymatic reactions were smoothly carried out. Substrate immobilization on GF for the solid-phase acetylene coupling reaction was achieved by electrochemical polymerization of the substrate precursor containing a pyrrole side chain, where the amount of substrate on the electrode surface was easily controlled by the number of repeated cyclic voltammetric scanning. Couplings between terminal acetylenes and the iodobenzene-modified GF electrode or aromatic iodides and the terminal acetylene-modified GF electrode in the presence of palladium catalyst proceeded smoothly with satisfactory yields.
\end{abstract}

Key words — mediator, modified electrode; electrolysis; oxidation; reduction; solid-phase synthesis

\section{1. はじめに}

1975 年 L. L. Miller らが光学活性グラファイト 電極を用いた不斉電解還元反応を発表1)して以来, 電極界面を原子・分子レベルで組織化した “修飾電 極”に関する研究は活発に行われるようになり，今 日では電気化学のみならず多くの関連学問・研究分 野において新しい先駆的な学問・研究の潮流となつ てきている。当初は裸の電極の表面に機能性物質 （メディエーター, Med）を化学的に結合させる修 飾法が用いられたが，Medの修飾方法，修飾量， 安定性，寿命などを十分解決することができず，電

奥羽大学薬学部（T963-8611 福島県郡山市富田町字三 角堂 31 番)

e-mail: y-kashiwagi@pha.ohu-u.ac.jp

本総説は, 平成 18 年度日本薬学会東北支部奨励賞の受

賞を記念して記述したものである。
解重合法, 高分子膜被覆法などの高分子層に機能性 物質を固定する研究が発展している，有機電解合成 は，電極界面で進行するため，特異な界面上での特 異な反応が期待され， Miller らの修飾電極もこの目 的に沿つたものであったが，有機電解合成の研究の 多くは裸の電極で行われているのが現状である．問 題点は, 修飾電極では高電流が得られ難いこと, 安 定性，寿命が不十分なことにある。高電流を必要と しない用途，例えばセンサー，表示素子，記録素子 などの分野では実用段階に入っているものも多い.

筆者らは, 1980 年代の終わり頃から有機電解合 成に利用可能な修飾電極の作製を研究ターゲットと し，特に表面積の大きなグラファイトフェルト $\left(\mathrm{GF}, 0.7 \mathrm{~m}^{2} / \mathrm{g}\right)$ 電極上に高分子層を被覆し，つい で Med を高分子マトリックス中に化学結合により 導入した高分子修飾電極へと展開した. ${ }^{2)} \mathrm{Med}$ 修飾 
密度は, 約 $20 \mu \mathrm{mol} / \mathrm{cm}^{3}$, 電流は数 $\mathrm{A} / \mathrm{dm}^{2}, 1$ 回当 たりの基質反応量 $5 \mathrm{mmol} /$ 電極 $\mathrm{cm}^{2}$ （反応率 $100 \%$ で電極の再使用可能）であり，このような值は直接 的な化学修飾電極では達成できないものであった. 本稿では，この高分子修飾電極を用いた有機電解合 成，さらに最近ではこれらの研究発展として，固相 合成反応のための基質固定化電極の作製，機能性材 料を用いた有機電解合成の開発等に関する筆者らの 研究例について述べる.

\section{2. 高分子被覆メディエーター修飾 GF 電極の作} 製

基板電極として GF を用いて，Med の固定量を 大きくするためにポリアクリル酸（PAA）の薄層 被覆を試みた。PAA は，GF に強吸着しかつ触媒 の働きをする Med を化学的に固定できるカルボキ シル基を有するとともに，高分子層の厚さを制御し 易い性質を有する。 $0.25 \% \mathrm{PAA} /$ メタノール溶液に GF を浸漬して得た高分子層の厚さは，約 $40 \mathrm{~nm}$ で あり電極反応に適した層厚であった。 ${ }^{2)}$

この GF に被覆された PAA 層は，アセトニトリ ル， $N, N$ - ジメチルホルムアミドなどの非プロトン 性溶媒には不溶であり，2,2,6,6- テトラメチルピペ リジニル -1-オキシル (TEMPO)，フェロセン $(\mathrm{Fc})$ ，ビオローゲン（V）などの Med をアミド結 合，エステル結合などにより固定できた．固定量は 反応条件で制御が可能であった。

さらに，この修飾電極の高分子層の溶解性を低下 させるために $\alpha, \omega-$ アルキレンジアミンを用いて架 橋化反応を施した．検討したジアミン類のうちで は，ヘキサメチレンジアミンが最もよかった。妿 橋反応の別の効果は，基質などの物質移動，電極と Med との間の電子移動を行い易いドメインを高分 子層に形成するものと推定される.

最後に，PAA 層の残余のカルボキシル基をアル

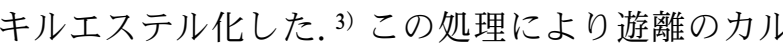

ボキシル基を皆無にでき，ドメインの物理的環境を 親水性から疎水性へ変化できる。電解反応によって は親水性雾囲気の方が好ましい場合もあり，そのと きにはエステル化の試薬，未反応のカルボキシル基 を残すような反応条件の調節によって制御できた.

以上のような設計に基づいた電気化学反応器（エ レクトロケミカルリアター) 用の TEMPO 修飾 GF 電極の作製法を Fig. 1 に示す.

3. 高分子被覆メディエーター修飾 GF 電極によ る有機物の電解触媒反応

3-1. ニトロキシルラジカル修飾 GF 電極を用い た電解触媒酸化反応 Med である TEMPO は,

Fig. 2 のレドックス反応を行う。ニトロソニウムイ オン（4）は強い酸化作用を有し，各種の有機物を 酸化した. ${ }^{4,5}$ ニトロキシルラジカル（3）から 4 へ の 1 電子酸化のピーク電位は $0.2 \mathrm{M}\left(\mathrm{mol} / \mathrm{dm}^{3}\right)$ 過 塩素酸ナトリウム/アセトニトリル中で $+0.6 \mathrm{~V}$ vs. $\mathrm{Ag} / \mathrm{AgCl}$ であるから, $+0.8-+1.0 \mathrm{~V}$ で定電位電解 を行った。標準的電解条件は, $\mathrm{H}$ 型セル（Nafion 117 の隔膜を使用)，修飾電極（陽極） $2.0 \times 5.0 \times$ $0.5 \mathrm{~cm}$ ，陽極液量 $40 \mathrm{ml}$ ，基質 $50 \mathrm{mmol}$ ，脱プロト ン反応を促進するための有機塩基 $50 \mathrm{mmol}, 0.2 \mathrm{M}$ 過塩素酸ナトリウム/アセトニトリル電解液であ り，定電位電解により基質の残存が認めなくなるま で行った．電解終了後，陽極液から生成物をカラム クロマトグラフィーなどにより分離取得し収量を求 めた. 生成物の同定は常法に従った.

3-1-1. アルコール類の酸化 一級及び二級ア ルコール類は，高電流効率，高選択的に対応するア ルデヒド及びケトンへ酸化された（Schemes 1 and 2). ${ }^{2,3)}$

ジオール類からは，ラクトンを生成した (Scheme 3).この反応は 2 電子反応で, Med のニトロソニ ウムイオン（4）はヒドロキシルアミン（2）まで還 元されものと推定される. また, 電解中電極の酸化

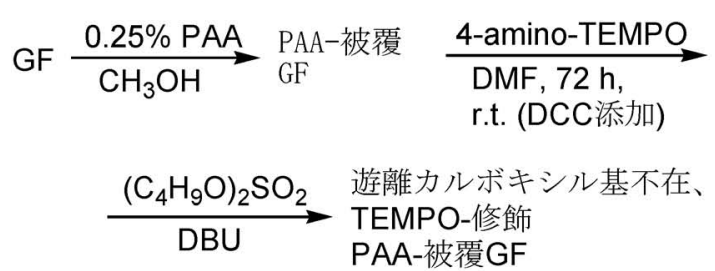

Fig. 1. Preparation Method of TEMPO-modified GF Electrode for Electroorganic Synthesis 


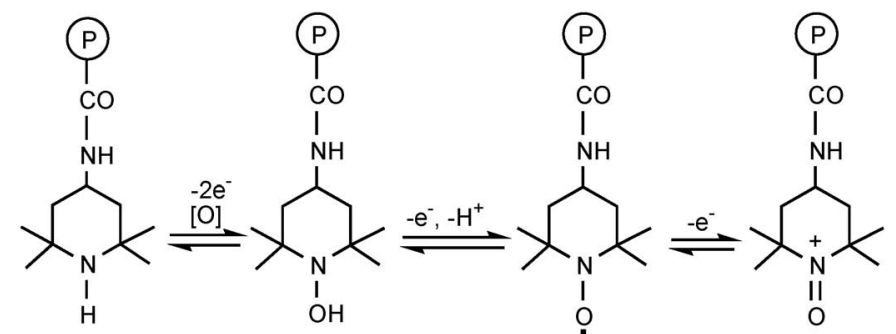

(1)

(2)

(3)

(4)

Fig. 2. A Reversible Redox System Based on TEMPO

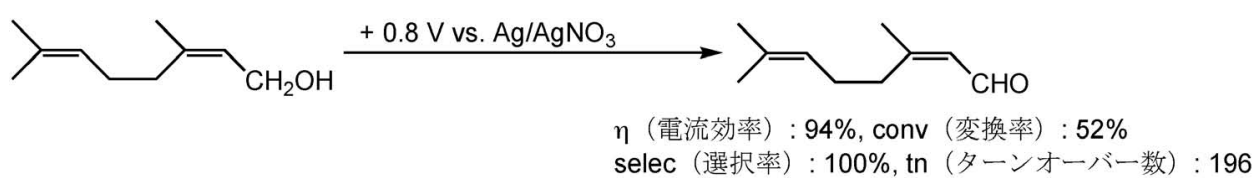

Scheme 1.

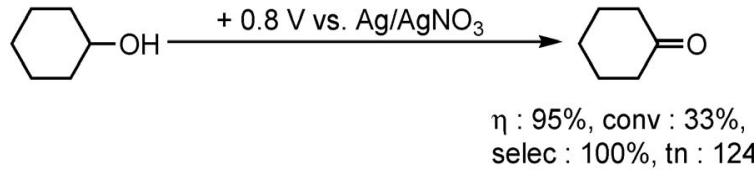

Scheme 2.
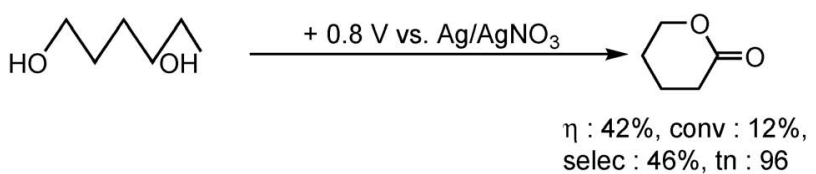

Scheme 3.

活性は徐々に低下するが, 反応後の電極を $m$ - クロ ロ過安息香酸/ジエチルエーテル液で処理すること により活性は復元された。

3-1-2. チオール類の酸化 高電流効率, 高選 択的に, チオール類はジスルフィドへ酸化された (Scheme 4). 5) 電解後も電極は不活性化せず，その まま再使用できた.

ジオールからはジチオランが主成するが，少量の 2 量体も副成した（Scheme 5)。電極はアルコール 類の場合ほごでないが不活性化した。

3-1-3. ナフトール類の酸化２-ナフトール及 び 2-メトキシナフタレンは $1,1^{\prime}$ - カップリング化合 物へ選択的に酸化された (Scheme 6).6) 1-ナフトー ル及び 1-メトキシナフタレンはカップリング位置 の異なる 3 種のカップリング化合物へ酸化される. 2- 及び 4- メチルキノリンはそれぞれ 4,4'- 及び
2,2'-カップリング化合物へ定量的に酸化された (Scheme 7). 7)

試薬酸化法と比較して，本法はビナフトール類を 簡便に，かつ選択的に生成するものであり，広い応 用が期待できる.

3-1-4. アミン類の酸化 アミン類は，無水条 件下ではニトリル体へ，含水条件下では中間体とし てイミン体を経由したのち，加水分解反応によりア ルデヒド体へ，いずれも高電流効率，高収率，高選 択率で変換できた (Scheme 8). ${ }^{8)}$

\section{3-2. キラルニトロキシルラジカル修飾 GF 電極} を用いた立体選択的電解触媒酸化反応 エナンチ 才選択的な反応及び不斉合成を行う目的で，分子内 に不斉炭素を導入したキラルニトロキシルラジカル を合成し，その修飾電極を作製した。 2,6- ルチジン 存在下, ラセミ体の 1- フェニルエタノールの電解触 媒酸化反応を行った結果を Table 1 に示す．3- 位に 不斉炭素を有する 2,2,5,5-tetramethyl-3-pyrrolimyl$N$-oxyl (PROXYL) 及び 2,2,8a-trimethyldecahydroquinolinyl- $N$-oxyl (QUINOXYL) では, いずれも工 ナンチ才選択的な酸化反応は進行せず， $R$-体， $S$ 体とも効率的にアセトフェノンに変換できる. ${ }^{9,10)}$ 一方，2,2,7-trimethyl-10-isopropyl-1-azaspiro [5.5] undecane- $N$-oxyl（SPIROXYL）を用いた場合には, $S$ - 体がエナンチオ選択的にアセトフェノンに酸化 し， $R$ - 体は未反応物として回収され，その光学純 度は $99 \%$ ee であった. ${ }^{11-14)}$ また, カンファー型キ ラルニトロキシルラジカル（CAMPHOXYL）を用 
2

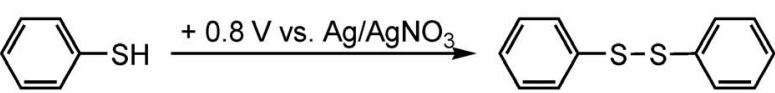

Scheme 4.

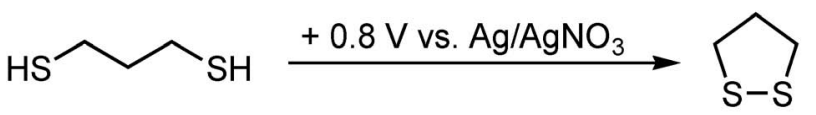

$\eta: 68 \%$

conv : $70 \%$

tn : 256

$\eta: 99 \%$

conv : $100 \%$

selec : $100 \%$

tn : 375

Scheme 5.

2

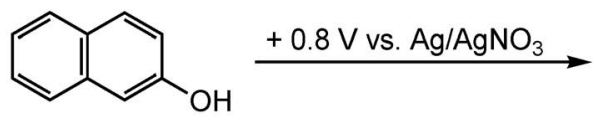

$\eta: 95 \%$ conv : $100 \%$ selec : $100 \%$ tn : 410

Scheme 6.

2<smiles>Cc1ccc2ccccc2n1</smiles><smiles>Cc1cc(-c2cc(C)nc3ccccc23)c2ccccc2n1</smiles>

$\eta: 91 \%$ conv : $100 \%$ selec : $100 \%$ th : 410

Scheme 7.

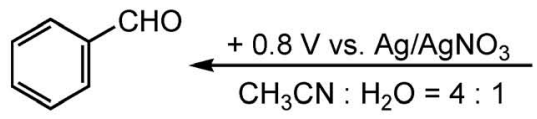

$\eta: 96.2 \%$

conv : $95.3 \%$

selec : $100 \%$

tn : 19.1

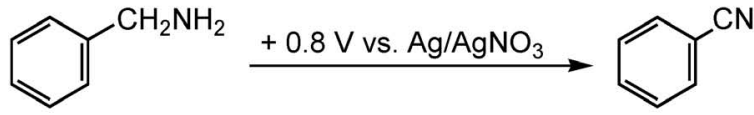

$\eta: 93.5 \%$ conv : $90.7 \%$ selec : $95.6 \%$ tn : 19

Scheme 8.

いた場合にも，同様なエナンチオ選択性を示し，未 反応物の光学純度は $64 \% e e$ であった.

ここで, 非常に高いエナンチオ選択能を示した SPIROXYL は分子内の $6,7,10$ - 位に 3 つの不斉炭 素が存在することから，このキラルニトロキシルラ ジカルのほかの異性体のエナンチオ選択能について 検討した.

SPIROXYL は，アセトニンとジヒドロカルボン を出発原料に合成されたが, 出発原料の関係上 4 種 類の絶対配置を有するキラルニトロキシルラジカル が生成した。その修飾電極を作製し，2,6-ルチジン
存在下ラセミ体の 1- フェニルエタノールの電解触 媒酸化反応を行った結果, $6 R, 7 R, 10 R$ の絶対配置 を有する SPIROXYL 修飾 GF 電極は，上記で示し た $6 S, 7 R, 10 R$ の絶対配置を有する SPIROXYL 修 飾 GF 電極とは異なり， $R$ - 体がエナンチオ選択的 にアセトフェノンに酸化し， $S$-体は未反応物とし て回収され，その光学純度は $99 \% e e$ であった. $6 R$, $7 S, 10 R$ の絶対配置を有する SPIROXYL 修飾 GF 電極は, 未反応物として回収される $S$ - 体の光学純 度は低下するものの $6 R, 7 R, 10 R$ の絶対配置を有す る SPIROXYL 修飾 GF 電極と同様のエナンチ才選 
Table 1. Enantioselective Electrocatalytic Oxidation of 1-Phenylethanol on Nitroxyl Radical Compound Modified GF Electrodes

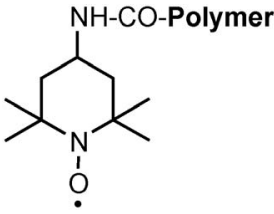

TEMPO

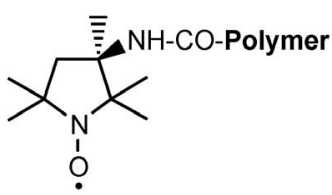

PROXYL

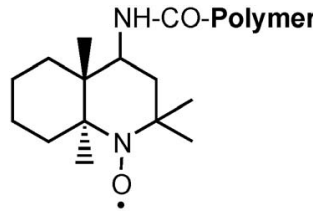

QUINOXYL

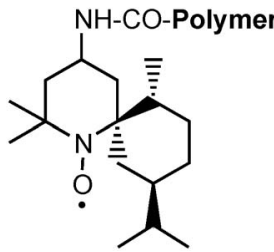

SPIROXYL

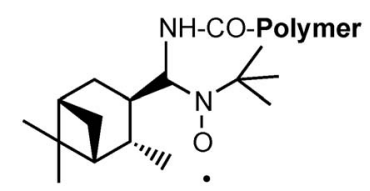

CAMPHOXYL
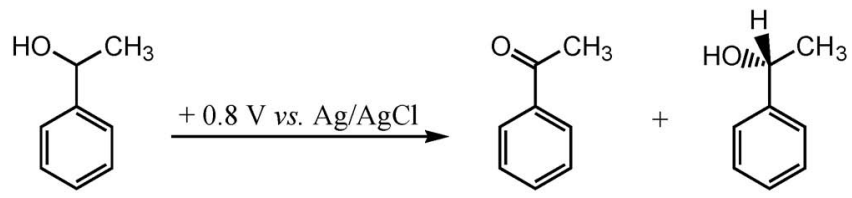

racemate

acetophenone

recovery alcohol

\begin{tabular}{cccccccc}
\hline \hline Nitroxyl radical & Catalyst/ $\mu$ mol & Recovery alcohol & Charge/C & Current efficiency/\% & Conv./\% & Ee/\% & Turnover number \\
\hline $\mathbf{1}$ & 12.2 & $\ldots \ldots$ & 228.3 & 98.2 & 96.8 & 0 & 79.3 \\
$\mathbf{2}$ & 13.8 & $\ldots \ldots$ & 235.6 & 92.1 & 93.7 & 0 & 67.9 \\
$\mathbf{3}$ & 9.4 & $\ldots \ldots$ & 233.0 & 94.8 & 95.4 & 0 & 101.5 \\
$\mathbf{4}$ & 7.1 & $R$-isomer & 117.8 & 99.1 & 50.4 & 99 & 74.1 \\
$\mathbf{5}$ & 8.9 & $R$-isomer & 215.6 & 95.6 & 88.6 & 20 & 99.6 \\
\hline
\end{tabular}

択性を示した。 $6 S, 7 S, 10 R$ の絶対配置を有する SPIROXYL 修飾 GF 電極は，ラジカルとオキソア ンモニウムイオン間の可逆的な電子移動が行われな かつたため, このような電解触媒酸化反応は進行し なかった。

種々のラセミアルコール類について， $6 S, 7 R$, $10 R$ の絶対配置を有する SPIROXYL 修飾 GF 電極 を用いた電解触媒酸化反応を行った結果を Table 2 に示す， $\alpha$ - 位に不斉炭素を有するいずれの二級ラ セミアルコールに対して， $S$ - 体がエナンチオ選択 的に相当するケトン体に酸化され， $R$-体は未反応 物として高い光学純度で回収された。 また，この反 応を $6 R, 7 R, 10 R$ の絶対配置を有する SPIROXYL 修飾 $\mathrm{GF}$ 電極を用いることにより， $R$ - 体がエナン チ才選択的に相当するケトン体に酸化し， $S$ - 体を 未反応物として高い光学純度で回収された。一方, $\beta$ - 位に不斉炭素を有する一級ラセミアルコールで ある，2-フェニル-1-プロパノールにおいては，エ ナンチオ選択的な反応は進行せず， $R$-体， $S$-体い ずれも効率的に相当するアルデヒド体に変換され， その生成物のラセミ体として与えられた。

この SPIROXYL 修飾 GF 電極を用いたエナンチ 才選択的な酸化反応は，ラセミアミン類においても
同様なエナンチオ選択能を示し， $\alpha$-位に不斉炭素 を有するいずれの一級ラセミアミンに対して，一方 の異性体をイミン体を経て加水分解により相当する ケトン体に変換し，他方の異性体は未反応物として 高い光学純度で回収された（Table 3). 15,16）また, ラセミアルコールの時と同様， $\beta$ - 位に不斉炭素を 有する一級ラセミアミンでは，エナンチオ選択的な 反応は進行せず， $R$ - 体， $S$ - 体いずれも効率的に相 当するアルデヒド体に変換され，その生成物のラセ ミ体として与えられた。

これらの結果から，スピロ型キラルニトロキシル ラジカル修飾 GF 電極を用いることにより， $\alpha$-位 に不斉炭素を有する二級ラセミアルコール及び一級 ラセミアミンの電気化学的な光学分割が行えること が示唆された.

また, $6 R, 7 R, 10 R$ の絶対配置を有する SPIROX$\mathrm{YL}$ 修飾 GF 電極を用いた分岐アルカンジオール類 に電解触媒酸化反応においては， $R-1,4-$ ペンタンジ オールは立体が保持された $R$ - 体の光学活性なラク トン体へ高電流効率，高収率，高選択率で変換でき た。さらに，プロキラルなジオールである，3-メ チル -1,5- ペンタンジオール及び cis-1,2- シクロヘ キサンジメタノールにおいては，それぞれ相当する 
Table 2. Enantioselective Electrocatalytic Oxidation of Racemic Alcohols Using $(6 S, 7 R, 10 R)$-SPIROXYL Modified GF Electrode

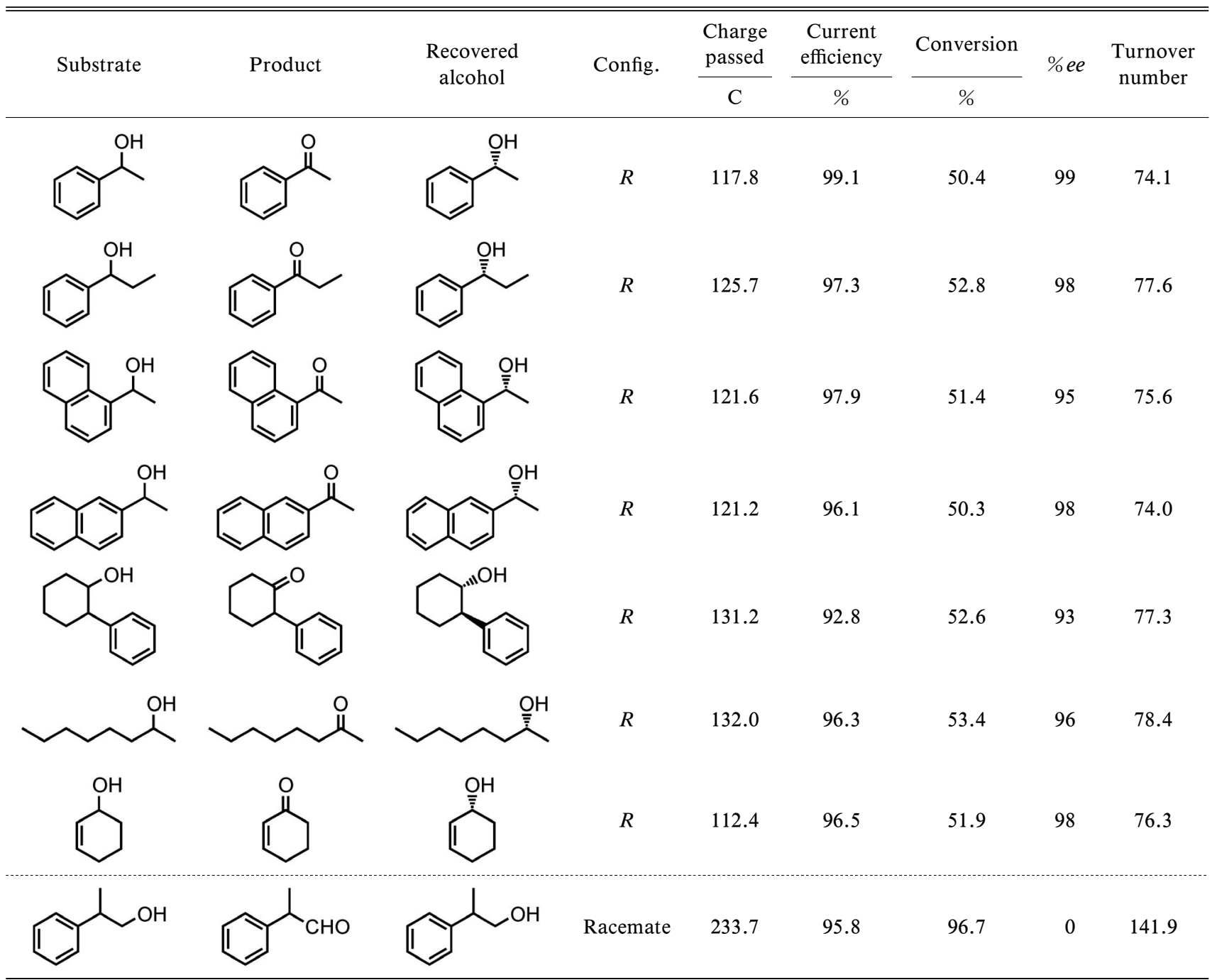

$R$ - 体及び $1 S, 6 R$ - 体の光学活性なラクトン体へと 高電流効率，高収率，高選択率で変換できた（Table 4). ${ }^{17)}$ この反応は $6 S, 7 R, 10 R$ の絶対配置を有 する SPIROXYL 修飾 GF 電極を用いた場合には, $S$ - 体の光学活性なラクトン体へと変換することが 可能であった.

3-3. ニッケルサイクラム修飾 GF 電極を用いた 電解触媒還元反応 ラジカル環化反応は，立体, 位置あるいは化学選択的に環構築を行う炭素-炭素 結合反応として天然物合成に幅広く利用されてい る。しかしながら，一般的には有機スズ等を用いる ため試薬の毒性が強くまた高価であること，試薬由 来の副生成物と目的生成物との分離，精製が困難で ある等の問題がある。そこで，本反応を Med とし てニッケルサイクラム誘導体を PAA 被覆 GF 電極
に固定した修飾電極を用いた電解触媒還元反応によ り検討した。 その結果, $\mathrm{NH}_{4} \mathrm{Br}$ 存在下 $-1.5 \mathrm{~V}$ で定 電位電解還元を行うと，ブロモアルキルシクロヘキ セノン類は脱ハロゲン化によるラジカル環化反応に より，目的とする双環化合物を効果的に得ることが できた (Table 5). ${ }^{18)}$

このニッケルサイクラム修飾 GF 電極は，ハロゲ ン化合物と活性オレフィンとのラジカル付加反応を も高電流効率，高収率，高選択性で達成できた。 た，カルボニル化合物の還元反応を行ったところ， いずれの基質に対してもモノハイドリックアルコー ル類とピナコール類の混合物を与えた. ${ }^{19)}$ さらに, ハロゲン化合物の脱ハロゲン化も効率的に進行した ことから, ${ }^{20)}$ 今日問題となっているダイオキシンや トリハロメタン等の有機ハロゲン類の分解反応に応 
Table 3. Enantioselective Electrocatalytic Oxidation of Racemic Amines Using $(6 S, 7 R, 10 R)$-SPIROXYL Modified GF Electrode

\begin{tabular}{|c|c|c|c|c|c|c|c|c|}
\hline Substrate & Product & $\begin{array}{c}\text { Recovered } \\
\text { alcohol }\end{array}$ & Config. & $\begin{array}{c}\begin{array}{c}\text { Charge } \\
\text { passed }\end{array} \\
\mathrm{C}\end{array}$ & $\begin{array}{c}\begin{array}{c}\text { Current } \\
\text { efficiency }\end{array} \\
\%\end{array}$ & $\frac{\text { Conversion }}{\%}$ & $\% e e$ & $\begin{array}{c}\text { Turnover } \\
\text { number }\end{array}$ \\
\hline & & & $R$ & 241.6 & 98.5 & 51.4 & 98 & 173.7 \\
\hline & & & $R$ & 268.4 & 96.8 & 56.1 & 95 & 189.6 \\
\hline & & & $R$ & 262.8 & 95.7 & 54.3 & 92 & 183.5 \\
\hline & & & $R$ & 250.8 & 97.3 & 52.7 & 96 & 178.1 \\
\hline & & & Racemate & 461.6 & 96.1 & 95.8 & 0 & 281.7 \\
\hline
\end{tabular}

Table 4. Asymmetric and Stereoselective Lactonization of Diols Using $(6 R, 7 R, 10 R)$-SPIROXYL Modified GF Electrode

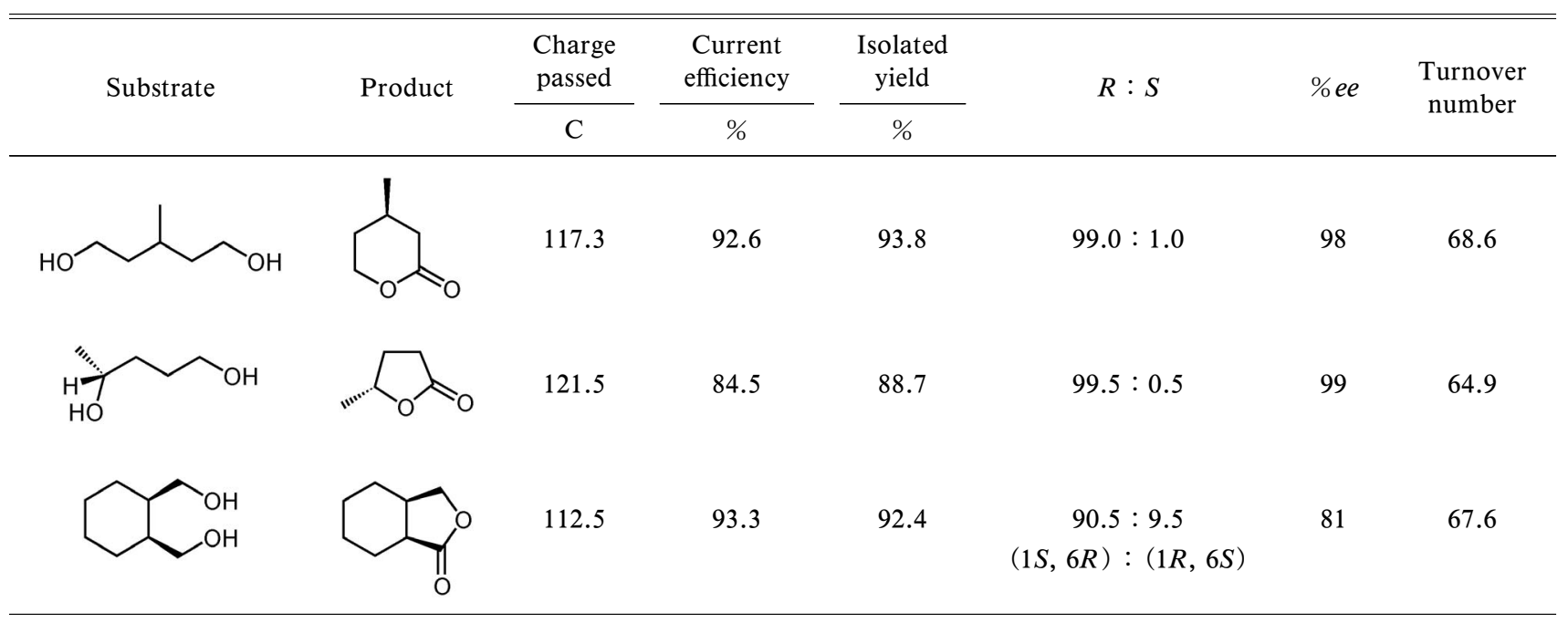

用でき，環境化学分野への貢献も期待できる.

\section{3-4. 金属微粒子担持ビオローゲン修飾 GF 電極} を用いた電解触媒水素化反応＼cjkstart遷移金属を用いた オレフィン類の接触水素化反応は，有機合成におい て非常に重要な反応であるが，一般的には水素ガス を用いて高温加圧下で反応が行われる。そこで本反 応を電解液中にプロトン源を共存させることにより 水素ガスを用いずに常温常圧下で行うために，遷移
金属微粒子（白金，パラジウム，ロジウム）を担持 したビオローゲン修飾 GF 電極を作製し検討し た. ${ }^{21)}$

同一分子内にカルボニルとオレフィンが共存する 基質は，パラジウムを担持した修飾電極を用いると オレフィン部分のみを高電流効率，高収率，高選択 的に水素化した。ただ高高い isophorone は水素化 が低電流効率，低収率であったために，パラジウム 
Table 5. Electrocatalytic Cyclization of Ni-cyclam Derivative Modified GF Electrode

\begin{tabular}{|c|c|c|c|c|c|c|c|}
\hline Substrate & Product & & $\begin{array}{c}\text { Charge } \\
\text { passed/C }\end{array}$ & $\begin{array}{c}\text { Current } \\
\text { efficiency/\% }\end{array}$ & Yield/\% & Conv./\% & $\begin{array}{c}\text { Turnover } \\
\text { number }\end{array}$ \\
\hline & & $\mathrm{n}=4$ & 189.4 & 87.6 & 86 & 92 & 1433 \\
\hline & & $\mathrm{n}=5$ & 168.6 & 61.8 & 54 & 65 & 900 \\
\hline & & $\mathrm{n}=4$ & 95.4 & 84.9 & 42 & 88 & 700 \\
\hline & & $\mathrm{n}=5$ & 202.6 & 71.4 & 75 & 75 & 1250 \\
\hline
\end{tabular}

Table 6. Electrochemical Hydrogenation on Graphite Felt/ (Poly (acrylic acid)-Viologen)-Metal Microparticles Electrode

\begin{tabular}{|c|c|c|c|c|c|}
\hline Substrate & Metal cat. & $\begin{array}{l}\text { Consumed current } \\
\text { (electron molecule }^{-1} \text { ) }\end{array}$ & Product & $\begin{array}{c}\text { Current } \\
\text { efficiency }(\%)\end{array}$ & Yield (\%) \\
\hline & $\operatorname{Pd}\left(2 \times 10^{-3}\right.$ eq. $)$ & 2 & & 10 & 15 \\
\hline & $\mathbf{R h}\left(6 \times 10^{-4}\right.$ eq. $)$ & 2 & & 35 & 42 \\
\hline & $\mathbf{R h}\left(2 \times 10^{-3}\right.$ eq. $)$ & 2 & & 62 & 68 \\
\hline & $\mathbf{R h}\left(2 \times 10^{-3}\right.$ eq. $)$ & 4 & & 47 & 94 \\
\hline \multirow{3}{*}{$\| \mathbb{}$} & $\operatorname{Pd}\left(5 \times 10^{-3}\right.$ eq. $)$ & 2 & & 72 & 76 \\
\hline & Pt $\left(5 \times 10^{-3}\right.$ eq. $)$ & 2 & & 63 & 67 \\
\hline & $\mathbf{R h}\left(5 \times 10^{-3}\right.$ eq. $)$ & 2 & & 62 & 65 \\
\hline
\end{tabular}

原子よりも直径の大きいロジウムを担持させ接触表 面積を大きくすることにより電流効率並びに収率を 改善することができた（Table 6).

一方，末端オレフィンを有する styrene において もパラジウムを担持した修飾電極を用いることによ り効率的にオレフィンを水素化することができた. また，この遷移金属微粒子を担持したビオローゲン 修飾電極は，オレフィンの水素化反応以外に，アセ チレン類の水素化，ニトリル及びニトロ基のアミノ 基への還元，さらにはアルデヒド類のアルコール類 への変換をも高電流効率, 高収率, 高選択性で達成 できた.

\section{4. メディエーターー酵素共修飾 GF 電極の作製}

酵素は電子移動を行う活性中心（FADH 等）が 絶縁性の蛋白質で覆われているため, 電極と直接電 子移動が困難である、そこで, 酵素の活性中心と電 極間の電子移動を可能にする Med を媒介させるこ とにより，Med-酵素修飾 GF 電極を用いたバイオ エレクトロケミカルリアクターを構築した. Med酵素反応系は，これまでに Rh (bpy) -HLADH, ${ }^{22}$
Fc-p- クレゾールメチルヒドロキシラーゼ23)の系が Steckhan らにより報告されている。しかし，これ らは Med のみが固定化されているもの, 22) あるい は双方とも溶液中に存在するものであった. ${ }^{23)}$

4-1. フェロセンー酵素共修飾 GF 電極を用いた 電解触媒酸化反応 固定した Fc のメディエーシ ヨン反応は，アミノフェロセンよりアミノエチルフ

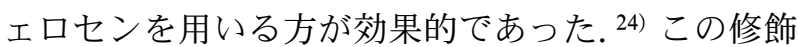
電極にさらに酸化還元酵素のジアホラーゼ（EC 1.8.1.4, Dp）を固定すると，電極は $\mathrm{NADH}$ を高電 流密度, 高収率で, 定量的に $\mathrm{NAD}^{+}$へ酸化した. ${ }^{25)}$ この $\mathrm{Fc}-\mathrm{Dp}$ 共修飾 $\mathrm{GF}$ 電極はアルコール類の酸化 反応に活性を示さなかったため, さらにNADH と アルコールデヒドロゲナーゼ（EC 1.1.1.1, ADH） を固定した多元酵素固定電極を作製し，アルコール 類の選択的酸化反応を実現できた. ${ }^{26)}$ 水溶液には pH 7.2 のリン酸緩衝液を用い，基質濃度 $50 \mathrm{mmol} /$ 1 を加えた。基質は残存しなかったので，反応液か らの生成物の回収，精製は容易であり，クリーンな 生物電気化学反応系を与えた。この Fc-NADH-Dp 
Table 7. Electroenzymatic Oxidation of Alcohols on Fc-, Dp-NADH and ADH-Multimodified GF Electrode

\begin{tabular}{|c|c|c|c|c|c|c|}
\hline Substrate & Product & $\begin{array}{c}\text { Charge } \\
\text { passed/C }\end{array}$ & $\begin{array}{c}\text { Currnt } \\
\text { efficiency } / \%\end{array}$ & $\begin{array}{l}\text { Isolated } \\
\text { yield/\% }\end{array}$ & $\% e e$ & $\begin{array}{c}\text { Turnover number } \\
\text { of } \mathrm{Fc}\end{array}$ \\
\hline & & 988 & 96.1 & 98.4 & 0 & 171 \\
\hline & & 974 & 89.4 & 90.2 & 98 & 157 \\
\hline & & 1005 & 90.8 & 94.5 & 99 & 164 \\
\hline & & 1018 & 91.8 & 96.8 & 96 & 168 \\
\hline
\end{tabular}

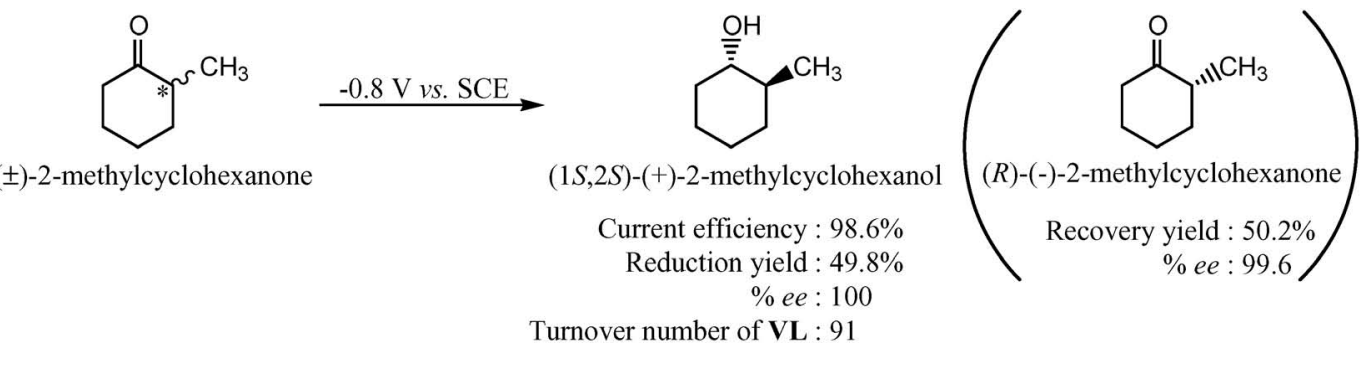

Scheme 9.

-ADH 複合修飾 GF 電極は，アルコール類を相当 するカルボニル化合物に酸化するとともに，ジオー ル類においては対応する光学活性なラクトン類を高 電流効率，高収率，高選択性で導いた（Table 7).

4-2. ビオローゲンー酵素共修飾 GF 電極を用い た電解触媒還元反応Ｍed としてビオローゲン 誘導体を用いたビオローゲン一 $\mathrm{NAD}^{+}-\mathrm{Dp}-\mathrm{ADH}$ 複 合修飾 GF 電極は, カルボニル化合物類を相当する アルコール類へ還元するとともに，ラセミケトン類 の一方の異性体を光学活性なアルコールへ高電流効 率，高収率，高選択性で不斉還元するのと同時に， 他方の異性体も未反応物として高い光学純度で回収 した (Scheme 9, 10). 27-30)

\section{5. 基質固定化電極の作製と固相合成反応への応} 用

固相反応は溶液中と比べて選択性や精製の容易さ に優れていることから，近年急速に発展している.
そこで，電極を担体として基質を固定化した修飾電

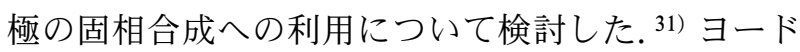
ベンゼンをペンダントに持つピロール誘導体は, 電 解重合時間を制御することによりその固定化量も制 御でき，さらにこの基質固定化 $\mathrm{GF}$ 電極を用いてア セチレンカップリング反応を試みたところ，ほぼ定 量的にカップリング反応が進行した（Scheme 11）. また，水酸基を有するアセチレン類については，力 ップリング反応終了後, ニトロキシルラジカルによ る水酸基部位の電解酸化反応を行えることも明らか となつた。

\section{6. おわりに}

高分子被覆 GFに Med，又はさらに酵素を固定 した電極は安定, 高電流密度, 高電流効率, 高選択 的に有機物を酸化できることを紹介した。この系は 多くの有機電解反応に適用できるばかりでなく，修 飾電極に特徵的な新しい反応の発見への可能性も十 
<smiles>CC1CCCC(=O)C1</smiles>

(士)-3-methylcyclohexanone

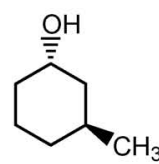

$(1 S, 3 S)-(-)-3-m e t h y l c y c l o h e x a n o l$

Current efficiency : $96.5 \%$

Reduction yield : $51.7 \%$ $\%$ ee: 93.1

Turnover number of $\mathbf{V L}: 94$

Scheme 10 .

(n)

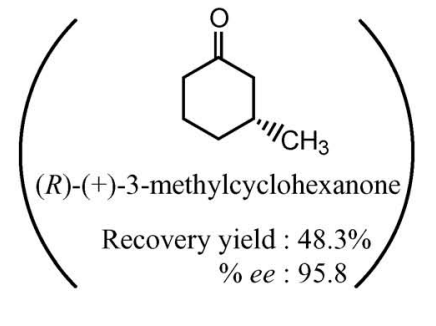

$(R)-(+)-3-$ methylcyclohexanone
Recovery yield : $48.3 \%$
$\%$ ee $: 95.8$
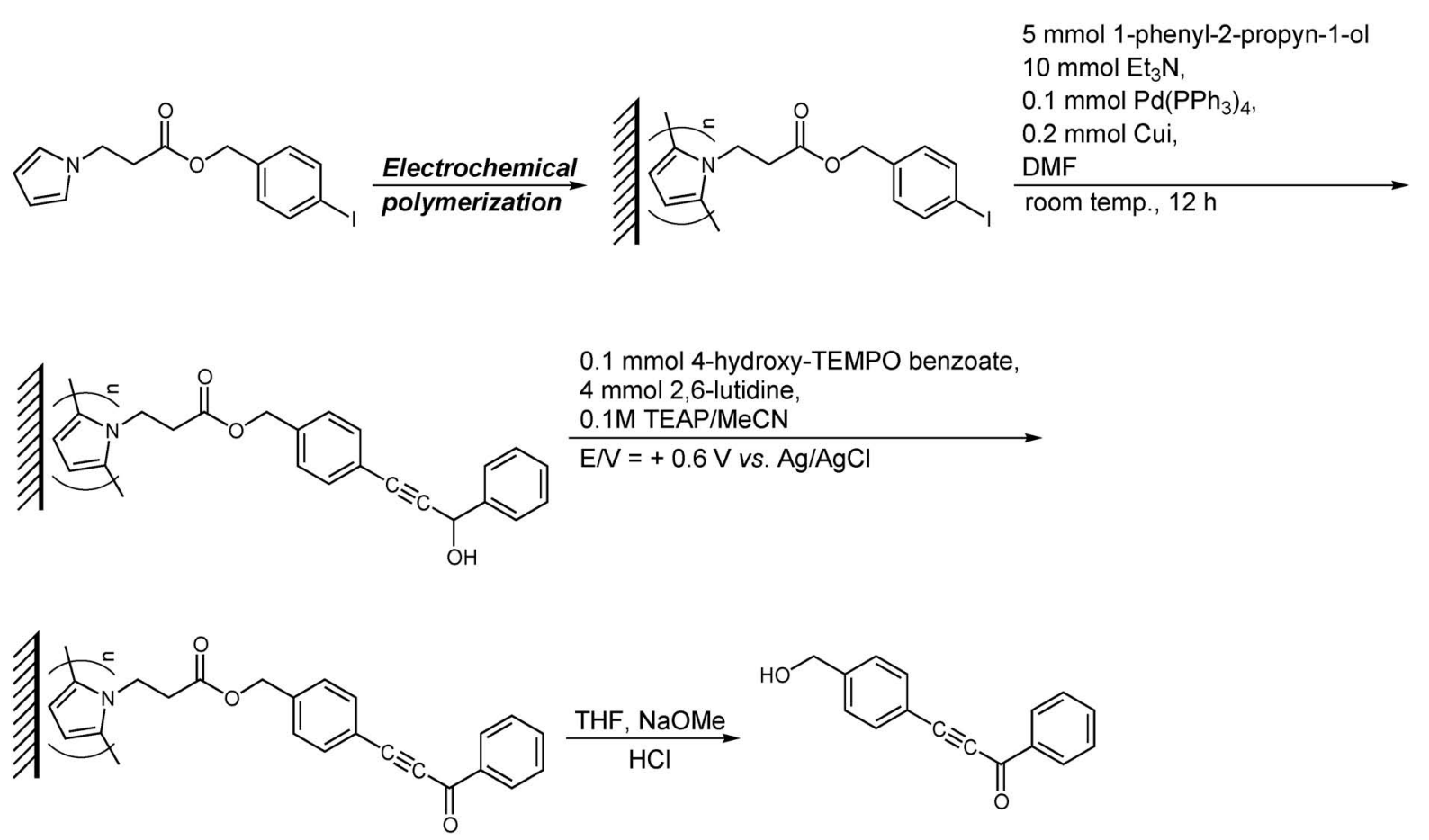

$76 \%$

Scheme 11 .

分ある. 今後, 多くの研究者の参画による展開を期 待している.

本研究は, 東北大学大学院薬学研究科及び奥羽大 学薬学部において行った研究であり, ご指導いただ きました長哲郎東北大学名誉教授並びに文献記載の 共同研究者の方々に厚く御礼申し上げます。また, 本研究は文部科学省, 日本学術振興会の科学研究費 によって遂行されたものであり，ここに感謝いたし ます.

\section{REFERENCES}

1) Watkins B. F., Dehling J. B., Kariv E., Miller L. L., J. Am. Chem. Soc., 97, 3549 (1975).

2) Osa T., Akiba U., Segawa I., Bobbitt J. M.,
Chem. Lett., 1988, 1423.

3) Osa T., Kashiwagi Y., Mukai K., Osawa A., Bobbitt J. M., Chem. Lett., 1990, 75.

4) Kaifer A. E., Bard A. J., J. Phys. Chem., 90, 868 (1986).

5) Park S. G., Aoki K., Tokuda K., Matsuda H., J. Electroanal. Chem., 195, 157 (1985).

6) Kashiwagi Y., Osawa A., Osa T., Ma Z., Bobbitt J. M., Chem. Lett., 1991, 581.

7) Kashiwagi Y., Ono H., Osa T., Chem. Lett., 1993, 81.

8) Kashiwagi Y., Ono H., Osa T., Chem. Lett., 1993, 257.

9) Kashiwagi Y., Kurashima F., Kikuchi C., Anzai J., Osa T., Bobbitt J. M., J. Chin. Chem. 
Soc., 45, 135 (1998).

10) Kurashima F., Kashiwagi Y., Kikuchi C., Anzai J., Osa T., Heterocycles, 50, 79 (1999).

11) Kashiwagi Y., Kurashima F., Anzai J., Osa T., Heterocycles, 51, 1945 (1999).

12) Kashiwagi Y., Uchiyama K., Kurashima F., Kikuchi C., Anzai J., Chem. Pharm. Bull., 47, 1051 (1999).

13) Kashiwagi Y., Kurashima F., Kikuchi C., Anzai J., Osa T., Bobbitt J. M., Tetrahedron Lett., 40, 6469 (1999).

14) Kashiwagi Y., Uchiyama K., Kurashima F., Anzai J., Osa T., Electrochemistry, 67, 900 (1999).

15) Kashiwagi Y., Chiba S., Anzai J., J. Electroanal. Chem., 566, 257 (2004).

16) Kashiwagi Y., Kurashima F., Kikuchi C., Anzai J., Osa T., Chem. Commun., 1999, 1983.

17) Kashiwagi Y., Uchiyama K., Kurashima F., Anzai J., Osa T., Anal. Sci., 15, 907 (1999).

18) Kashiwagi Y., Kurashima F., Chiba S., Anzai J., Osa T., Bobbitt J. M., Chem. Commun., 2003, 114.

19) Kashiwagi Y., Kikuchi C., Kurashima F., Ono T., Electrochim. Acta, 52, 2045 (2007).

20) Kashiwagi Y., Kikuchi C., Kurashima F., Anzai J., J. Organomet. Chem., 662, 9 (2002).
21) Kashiwagi Y., Kikuchi C., Anzai J., J. Electroanal. Chem., 518, 51 (2002).

22) Kashiwagi Y., Shibayama N., Anzai J., Osa T., Electrochemistry, 68, 42 (2000).

23) Steckhan E., Herrman S., Ruppert R., Dietz E., Frede M., Spika E., Organometallics, 10, 1568 (1991).

24) Frede M., Steckhan E., Tetrahedron Lett., 32, 5063 (1991).

25) Kashiwagi Y., Pan Q.-H., Yanagisawa Y., Shibayama N., Osa T., Denki Kagaku, 62, 1240 (1994).

26) Kashiwagi Y., Osa T., Chem. Lett., 1993, 677.

27) Osa T., Kashiwagi Y., Yanagisawa Y., Chem. Lett., 1994, 367.

28) Kashiwagi Y., Yanagisawa Y., Shibayama N., Nakahara K., Kurashima F., Anzai J., Osa T., Chem. Lett., 1996, 1093.

29) Kashiwagi Y., Yanagisawa Y., Shibayama N., Nakahara K., Kurashima F., Anzai J., Osa T., Electrochim. Acta, 42, 2267 (1997).

30) Kashiwagi Y., Pan Q.-H., Kurashima F., Kikuchi C., Anzai J., Osa T., Chem. Lett., 1998, 143.

31) Kashiwagi Y., Chiba S., Ikezoe H., Anzai J., Synlett, 14, 2513 (2004). 